\title{
KEDUDUKAN DAN HAK ANAK LUAR NIKAH PASCA PUTUSAN MAHKAMAH KONSTITUSI NOMOR 46/PUU-VIII/2010 TENTANG STATUS ANAK LUAR NIKAH
}

\author{
Nurul Hak \\ Pascasarjana IAIN Bengkulu \\ Jl. Raden Fatah Pagar Dewa Bengkulu \\ Email: nurul_hak@iainbengkulu.ac.id
}

\begin{abstract}
This article describes that since the ruling of the Constitutional Court No. 46/ PUU-VIII / 2010 concerning the status of children out of wedlock, there are pros and cons in the community in responding to the decision. Because this decision is on the one hand different from the provisions in Law No. 1 of 1974 and contrary to the fatwa of the Indonesian Ulama Council No. 11 of 2010 concerning the position of adultery children and treatment of them, on the other hand in their implementation requires implementation regulations which up to now do not yet exist. In the decision of the Constitutional Court it became clear the legal position of zina children or children born without going through the door of marriage, as illegitimate children, he only had a civil relationship with his mother and his mother's family. For men who cause their birth to be subject to ta'zir punishment, by providing a living and living necessity, the punishment is solely to provide protection for the child, so that the child gets the proper life insurance. The civil relationship of the child of adultery results does not cause a nasab relationship, but requires the biological parents to provide a guarantee of life for their child. If an adultery child is a woman, if she wants to get married, then the right to become a guardian is the guardian of the judge, while her parents, in this case her biological father is obliged to hold the marriage ceremony.
\end{abstract}

Keywords: children out of wedlock, the Constitutional Court, Islamic law

\begin{abstract}
Abstrak: Artikel ini mendeskripsikan bahwa sejak keluarnya putusan Mahkamah Konstitusi No. 46/PUU-VIII/2010 tentang status anak luar nikah, terjadi pro dan kontra di masyarakat dalam menyikapi putusan tersebut. Sebab putusan ini di satu sisi berbeda dengan ketentuan dalam UU No. 1 tahun 1974 dan bertentangan dengan fatwa Majelis Ulama Indonesia No. 11 Tahun 2010 tentang kedudukan anak zina dan perlakuan terhadapnya, di sisi lain dalam implementasinya memerlukan peraturan pelaksanaannya yang hingga kini belum ada. Dalam putusan Mahkamah Konstitusi tersebut menjadi jelas kedudukan hukum anak zina atau anak yang dilahirkan tanpa melalui pintu pernikahan, sebagai anak tidak sah, ia hanya memimiliki hubungan perdata dengan ibunya dan keluarga ibunya. Bagi laki laki yang menyebabkan kelahirannya dapat dikenakan hukuman ta'zir, dengan memberikan nafkah dan kebutuhan hidup, hukuman tersebut semata-mata untuk memberikan perlindungan terhadap anak, sehingga anak memperoleh jaminan kehidupan yang selayaknya. Hubungan perdata anak hasil zina tidak menyebabkan hubungan nasab, tetapi mewajibkan orang tua biologisnya memberikan jaminan kehidupan bagi anaknya. Seandainya anak zina adalah seorang perempuan, apabila mau menikah, maka yang berhak menjadi wali adalah wali hakim, sedangkan orang tuanya, dalam hal ini bapak biologisnya berkewajiban menyelenggarakan pesta nikahnya.
\end{abstract}

Kata kunci: anak luar nikah, Mahkamah Konstitusi, hukum Islam

\section{Pendahuluan}

Diskursus mengenai kedudukan dan hak anak luar nikah telah menjadi persoalan dalam Islam sejak pertama kali masa perkembangannya. Persoalan anak luar nikah telah menjadi persoalan yang mengemuka sebagai sebuah dilema dalam kehidupan masayarakat, yang harus dicarikan jalan keluarnya. Anak hasil hubungan luar nikah sering menjadi korban, padahal mereka membutuhkan perlindungan secara hukum untuk memperoleh hak-haknya sebagaimana layaknya seorang anak, karena mereka sesungguhnya tidak bersalah, mereka hanya menanggung derita dan menjadi korban 
akibat perbuatan kedua orang tuanya.

Di Indonesia, pro dan kontra dalam masalah kedudukan dan hak anak luar nikah terjadi, mulai dari hukum perdata yang berlaku di Indonesia yaitu BW, lalu dalam Undang-Undang Nomor 1 Tahun 1974, Putusan Mahkamah Konstitusi hingga fatwa Majelis Ulama Indonesia (MUI), ${ }^{1}$ belum ditemukan format baru hukum yang lebih adil bagi kedudukan dan hak anak luar nikah, yang dapat diterima oleh banyak pihak, khususnya umat Islam di Indonesia. ${ }^{2}$ Sementara peraturan pelaksanaannya mengenai hak dan kedudukan anak luar nikah hingga saat ini belum ada.

Ada semacam dis-harmonis antar peraturan dan perundang-undangan, termasuk juga dengan putusan Mahkamah Konstitusi. Di samping itu, perlu ada sinergitas pemahaman terhadap berbagai peraturan yang ada, yang mampu menjembatani persoalan anak luar nikah tersebut, sehingga dalam memahami peraturan dan perundangundangan, terutama yang ada hubunganya dengan hak-hak anak luar nikah, tidak terjadi disparitas, pemahaman yang berbeda beda.

\section{Problematika Anak Luar Nikah}

Untuk menentukan kedudukan dan hak anak luar nikah, maka harus jelas asal usul anak, nasab anak serta statusnya dimata hukum. Nikah adalah satu satunya jalan dalam rangka memelihara kemurnian nasab. ${ }^{3}$ Islam Juga mengharamkan zina, karena zina akan menyebabkan terpeliharanya hubungan nasab tidak sah. ${ }^{4}$

Nasab seorang anak, bagaimanapun kondisinya, akan tetap kembali kepada ibunya, hal ini ditegaskan dalam firman Allah Swt:

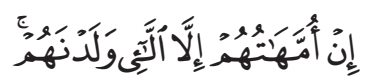

\section{"Sesungguhnya Ibu-ibu mereka tidak lain hanya-}

${ }^{1}$ Fatwa Majelis Ulama Indonesia (MUI) nomor 11 Tahun 2010 tentang kedudukan anak zina dan perlakuan terhadapnya.

${ }^{2}$ Anshary, Kedudukan Anak Dalam Perspektif Hukum Islam dan Hukum Nasional, (Bandung: Mandar Maju, 2014), h. v

${ }^{3}$ Nurul Irfan, Nasab dan Status Anak Dalam Hukum Islam, (Jakarta: Penerbit Amzah, 2012), h. 8.

${ }^{4}$ Nurul Irfan, Nasab dan..., h. 9. lah wanita yang melahirkan mereka". (Q.S. AlMujadalah: 2).

Para ulama sepakat mengatakan bahwa perzinaan bukan penyebab timbulnya nasab anak dengan ayah, sehingga anak zina tidak boleh dihubungkan dengan nasab ayahnya, meskipun secara biologis berasal dari benih laki laki yang menzinai ibunya. Alasannya bahwa nasab merupakan karunia dan nikmat, sedangkan perzinaan merupakan tindak pidana (jarimah) yang sama sekali tidak layak mendapatkan balasan nikmat, ${ }^{5}$ melainkan balasan berupa hukuman, baik rajam, dera seratus kali maupun pembuangan. ${ }^{6}$ Selain itu alasan yang paling kuat adalah sabda Nabi dalam sebuah hadis yang diriwayat dari Abu Hurairah:

$$
\text { الولد للفراث و للعاهرالحجر (رواه مسلم) }
$$

"Anak itu bagi yang meniduri isteri (secara sah) yaitu suami, sedangkan bagi pezina ia hanya berhak mendapatkan batu (rajam)". (HR. Muslim). ${ }^{7}$

Hadis di atas telah disepakati oleh para ulama dari berbagai kalangan madzhab, sebagai alasan bahwa perzinaan itu sama sekali tidak akan berpengaruh terhadap sebab-sebab ketetapan nasab antara anak dengan ayah biologis yang menzinai ibunya. ${ }^{8}$ Oleh sebab itu, sesuai dengan ayat serta hadis di atas, pengakuan nasab anak kepada bapaknya hanya melalui pernikahan yang sah an sich.

Berbeda dengan anak tidak sah, yakni yang

${ }^{5}$ Muhammad Abu Zahroh, Al Ahwal Asy-Syakhsiyyah, (Daar El Fikr Al 'Arobi, tt), h. 454.

${ }^{6}$ Imam Muslim bin al-Hajjaj, Shahih Muslim, jilid 2, hadis ke 3200, Lidwa Pustaka i Sofwer, Hadis Imam Sembilan.

${ }^{7}$ Imam Muslim bin al-Hajjaj, Shahih Muslim, jilid 2, hadis ke 1458, (Libanon: Dar al-Kutub al Ilmiyah, 2008), h. 375.

8 Dalam Kitab Sahih Bukhari hadis nomor 1936, sebagaimana dijelaskan, "Telah menceritakan kepada kami Zuhair bin Harb, telah menceritakan kepada kami Yazid bin Harun, telah mengabarkan kepada kami Husain Al Mu'allim dari 'Amr bin Syu'aib dari ayahnya dari kakeknya, ia berkata; seorang laki-laki berdiri dan berkata; wahai Rasulullah, sesungguhnya Fulan adalah anakku. Aku berhubungan dengan ibunya pada masa jahiliyah. Rasulullah shallallahu alaihi wasallam berkata; tidak ada pengakuan dalam Islam, telah hilang urusan jahiliyah, anak mengikuti pemilik ranjang, dan orang yang berzina tidak mendapat apapun". Lidwa Pustaka i Sofwer, Hadis Imam Sembilan. Lihat juga Nurul Irfan, Nasab dan..., h.115. 
dilahirkan akibat perzinaan, sedangkan anak luar nikah, yaitu anak yang dilahirkan akibat hubungan luar nikah, artinya orang tuanya menikah, tetapi pernikahannya tidak memiliki kekuatan hukum karena tidak tercatat. Baik anak tidak sah maupun anak luar nikah hanya memiliki hubungan perdata kepada ibunya dan keluarga ibunya, dalam keadaan seperti ini, posisi anak sangat dirugikan dalam berbagai aspek kehidupanya, baik secara sosiologis, psikologis maupun secara ekonomis.

Dalam konteks peraturan perundangundangan di Indonesia, seiring dengan berlakunya undang-undang yang mengatur tentang perkawinan, yaitu Undang-Undang Nomor 1 Tahun 1974, konsep anak sah sebagaimana disebutkan dalam pasal 42, berbunyi, anak sah adalah anak yang dilahirkan dalam atau sebagai akibat perkawinanyangsah. Sedangkan mengenai anak luar nikah sebagaimana disebutkan dalam pasal 43 ayat (1) menyebutkan, anak yang dilahirkan diluar perkawinan hanya mempunyai hubungan perdata dengan ibunya dan keluarga ibunya. Sedangkan pada pasal 43 ayat (2) menyebutkan, kedudukan anak tersebut ayat (1) ditas selanjutnya akan diatur dalam Perarturan Pemerintah. ${ }^{9}$ Demikian juga dalam Kompilasi Hukum Islam, pasal 99 menyebutkan, anak sah adalah, ayat (a) anak yang dilahirkan dalam atau akibat perkawinan yang sah, dan ayat (b) hasil perbuatan suami isteri yang sah diluar rahim dan dilahirkan oleh isteri tersebut. ${ }^{10}$

Yang menjadi persoalan, anak yang dilahirkan dari pernikahan yang tidak tercatat, yakni pernikahan yang dilaksanakan sesuai dengan aturan agama, artinya sah menurut agama (sesuai dengan pasal 2 ayat (1) Undang Undang Perkawinan), namun tidak tercatat (tidak sesuai dengan pasal 2 ayat (2) Undang Undang Perkawinan), sah menurut agama, tetapi tidak diakui menurut hukum negara. Pemahaman yang mendua, dikhotomis, dan berdisparitas,

${ }^{9}$ Lihat Undang Undang Nomor 1 Tahun 1974, pasal 42, 43 ayat (1) dan (2)

${ }^{10}$ Lihat Kompilasi Hukum Islam Pasal 99 ayat (a) dan (b). disatu sisi mengakui, disisi lain tidak mengakui. Inilah yang sering dipahami oleh masyarakat, pemahaman ini tentu saja lahir dari pemahaman terhadap Pasal 2 ayat (1) dan ayat (2) UndangUndang Nomor 1 Tahun 1974 Nomor 1 Tahun 1974. Pasal 2 ayat (1) menyatakan bahwa, Perkawinan adalah sah, apabila dilakukan menurut hukum masing-masing agamanya dan kepercayaannya itu. Sedangkan pasal 2 ayat (2) berbunyi, Tiap tiap perkawinan dicatat menurut perundang-undangan yang berlaku. ${ }^{11}$ Nikah Siri, apabila dilaksanakan memenuhi syarat dan rukun dalam Islam, berdasarkan pasal 2 ayat (1) dinyatakan sah, akan tetapi berdasarkan pasal 2 ayat (2), tidak diakui oleh negara, tidak memiliki kekuatan hukum, anak yang lahir dari pernikahan yang tidak tercatat atau nikah siri, sebagai anak luar nikah.

Putusan Mahkamah Konstitusi Nomor 46 /PUU-VIII/2010 tentang status anak luar nikah seolah olah mengubah tatanan status hukum anak luar nikah menjadi diakui, dengan ketentuan dapat dibuktikan secara ilmu pengetahuan. Putusan Mahkamah Konstitusi tentang status anak luar nikah tersebut, sempat menjadi isu yang menggemparkan dalam tatanan hukum perdata di Indonesia saat itu, khususnya umat Islam, dimana dalam putusan Mahkamah Konstitusi mengakui anak luar nikah memiliki hubungan keperdataan terhadap bapak biologisnya, sepanjang dapat dibuktikan secara ilmu pengetahuan memiliki hubungan darah dengan bapak biologisnya. ${ }^{12}$

Keluarnya putusan Mahkamah Konstitusi tentang status anak luar nikah, yang pada akhirnya menuai pro dan kontra di kalangan praktisi hukum, akademisi, tokoh agama dan masyarakat pada umumnya, baik mengenai isi putusannya yang dianggap melegalkan zina dan hubungan sek bebas, serta kerancuan dan

\footnotetext{
${ }^{11}$ Undang Undang Nomor 1 Tahun 1974 Lembara Negara RI Nomor 1 Tahun 1974.

${ }_{12}$ Moch. Isnaini, dalam I. Nyoman Sujana, Kedudukan Hukum Anak Luar Nikah dalam Perspektif Putusan Mahkamah Konstitusi Nomor 46/PUU-VIII/2010, (Jogyakarta: Aswaja Pressindo, 2015) h. iv
} 
multi tafsir tentang yang dimaksud dengan anak luar nikah, termasuk persoalan kekuatan hukum putusan Mahkamah Konstitusi tersebut, menjadi persoalan yang cukup komplek.

Namun demikian, dalam konteks ijtihad, putusan Mahkamah Konstitusi tersebut merupakan sebuah ijtihad spektakuler, meskipun putusan Mahkamah Konstitusi bagi sebagian kalangan dianggap telah menodai agama, hal ini yang kemudian Majelis Ulama Indonesia (MUI) mengeluarkan fatwa nomor 11 Tahun 2012 tentang anak zina dan perlakuan terhadapnya, dan menyatakan tidak akan mencabut fatwanya tentang anak zina, dimana dalam Fatwa MUI tersebut sejalan dengan pandangan fikih Islam pada umumnya, yaitu tidak mengakui anak zina memiliki hubungan perdata dengan bapak biologisnya. Rois Aam PB NU bahkan menginstruksikan kepada panitia Munas Alim Ulama 2012, untuk mengkaji ulang Putusan Mahkamah Konstitusi terkait putusannya tentang status anak luar nikah. ${ }^{13}$ Demikian juga Kementrian Agama bahkan menilai sebagai keputusan yang revolusioner. ${ }^{14}$

Apabila diamati, antara fatwa Majelis Ulama Indonesia (MUI) yang tidak mengakui anak zina memiliki hubungan perdata dengan Bapak biologisnya, ${ }^{15}$ dengan putusan Mahkamah Konstitusi yang mengakui anak luar nikah memiliki hubungan perdata dengan bapak biologisnya, ada persoalan yang berbeda. Dalam fatwa Majelis Ulama Indonesia (MUI) yang dimaksudkan adalah anak zina, yaitu anak yang dilahirkan dari hubungan seorang laki laki dengan seorang perempuan yang tidak terikat dengan perkawinan (tidak memenuhi pasal 2 ayat (1) dan ayat (2) Undang-Undang Nomor 1 Tahun 1974). Sedangkan dalam putusan Mahkamah Konstitusi

${ }^{13}$ Anshary, Kedudukan Anak..., h. vi.

${ }^{14}$ Kementerian Agama RI, Putusan Mahkamah Konstitusi Tentang Status Anak Hasil Nikah Siri Bisa Mengancam Eksistensi Lembaga Perkawinan, "Ikhlas Beramal", Media Informasi Kementrian Agama, Edisi 73 Februari 2012, h. 22-25.

15 Majelis Ulama Indonesia (MUI), Fatwa Majelis Ulama Indonesia Nomor: 11 tahun 2012 tanggal 18 Rabiul Akhir1433H/10 Maret $2012 \mathrm{M}$ tentang kedudukan anak hasil zina dan perlakuan terhadapnya. jika merunut latar belakang keputusannya, adalah anak luar nikah yang pernikahannya diakui oleh agama namun tidak tercatat (memenuhi ketentuan pasal 2 ayat (1) tetapi tidak memenuhi ayat (2) Undang-Undang Nomor 1 Tahun 1974), sehingga tidak diakui oleh hukum positif, yaitu nikah siri. Anak zina adalah anak tidak sah, sedangkan anak luar nikah adalah anak yang dilahirkan akibat pernikahan yang sah tetapi tidak diakui oleh negara, karena pernikahannya tidak tercatat.

\section{Hubungan Keperdataan}

Dalam kaitan hubungan keperdataan antara anak dengan orang tua, timbul akibat adanya kelahiran anak, tentu saja dimulai dengan adanya perkawinan kedua orang tuanya secara sah, anak yang lahir dari pernikahan yang sah memiliki hubungan keperdataan dengan ibu dan bapaknya yang sah. Sedangkan anak yang lahir diluar perkawinan yang sah, anak hanya memiliki hubungan perdata dengan ibunya dan keluarga ibunya.

Dalam Undang-Undang Nomor 1 Tahun 1974, pasal 43 ayat (1) anak yang dilahirkan di luar perkawinan hanya mempunyai hubungan perdata dengan ibunya dan keluarga ibunya. Konsep hubungan keperdataan seperti ini dinilai merugikan hak anak luar nikah, karena anak luar nikah tidak memperoleh hak hak keperdataan sebagaimana mestinya, padahal keadaan ini bukanlah kehendak dari anak, namun perbuatan kedua orang tuanyalah yang membuat keadaan menjadi demikian.

Istilah hubungan perdata yang digunakan oleh Pasal 43 ayat (1) Undang-Undang Perkawinan nampaknya hanya mentransfer apa adanya dari istilah yang digunakan oleh Pasal 280 KUH Perdata, yang dengan istilah tersebut akan menimbulkan akibat hukum yang berakibat timbulnya hak dan kewajiban dengan bapak biologisnya dalam hal memberi nafkah, perlindungan, perawatan dan kasih sayang, tetapi dalam konteks ini mencakup pula hak saling mewarisi, hak bapak biologis untuk menjadi wali nikah jika anak tersebut perempuan, dan 
penggunaan nama bapak biologis sebagai bin/ binti di belakang nama anak tersebut.

Hubungan keperdataan sebagaimana dijelaskan dalam hukum perdata mengandung implikasi yang luas meliputi waris mewarisi, hak menjadi wali, memberi nafkah, perlindungan dan menggunakan bin atau binti dibelakang nama anak. Dalam Islam istilah hubungan keperdataan terbatas, lebih sempit dibandingkan dengan hubungan nasab, hubungan keperdataan dalam Islam tidak mencakup hak waris mewarisi dan menjadi wali nikah, karena hak waris mewarisi dan menjadi wali hakim terikat dengan adanya hubungan nasab, sedangkan hubungan nasab dapat terbentuk dari adanya pernikahan yang sah.

Jika hubungan nasab hanya bisa terbentuk melalui pernikahan yang sah, maka hubungan keperdataan bisa saja terbentuk tanpa adanya ikatan perkawinan, tetapi karena adanya hubungan darah atau karena adanya hubungan yang lain, misalnya dalam kasus anak angkat.

Dalam kasus anak angkat yang sudah disahkan oleh pengadilan, akan menimbulkan hubungan keperdataan, hubungan keperdataan disini terbatas kewajiban melindungi, memberikan nafkah serta hak dan kewajiban keperdataan lainya, namun hubungan keperdataan disini tidak termasuk hak waris mewarisi dan hak menjadi wali nikah, serta penggunaan bin atau binti di belakangnya.

Demikian juga halnya dalam kaitan hubungan keperdataan anak luar nikah, hanya memiliki hubungan keperdataan dengan ibunya dan keluarga ibunya. Hubungan keperdataan dengan ibunya bebarti juga hubungan nasab, maka hubungan keperdataan disini juga meliputi hak waris, namun jika anak luar nikah tersebut perempuan, maka hak wali ada pada wali hakim.

Adapun terhadap anak luar nikah, bahwa yang dimaksud hubungan keperdataan dalam kaitan anak luar nikah dengan bapak biologisnya, tidak termasuk hubungan waris mewarisi maupun hak menjadi wali nikah. Dalam hal waris, bisa memperoleh bagian dengan jalan wasiat wajibah. Sedangkan dalam hal wali, jika anak luar nikah tersebut perempuan, maka yang menjadi wali adalah wali hakim, namun demikian, sebagai konsekwensi hubungan keperdataan tersebut, orang tuanya dalam hal ini bapak bniologisnya tetap berkewajiban menyelenggarakan walimahnya.

\section{Perbedaan Hubungan Nasab dan Hubungan Perdata Dalam Islam}

Dalam perspektif hukum Islam, dibedakan antara hubungan nasab dan hubungan perdata. Kata nasab (bhs. Arab) secara harfiah (ethimologi) berarti keturunan, pertalian darah, persaudaraan. ${ }^{16}$ Kata nasab yang telah menjadi bahasa Indonesia dan telah masuk dalam Kamus Besar Bahasa Indonesia, diartikan sebagai keturunan atau pertalian keluarga. ${ }^{17}$ Dalam ensiklopedi Islam, nasab diartikan sebagai keturunan atau kerabat, yaitu pertalian keluarga melalui akad nikah perkawinan yang sah. ${ }^{18}$ Demikian juga dalam Ensiklopedi Hukum Islam disebutkan, bahwa nasab adalah pertalian kekeluargaan berdasarkan hubungan darah sebagai salah satu akibat dari perkawinan yang sah. ${ }^{19}$

Sebagai akibat dari adanya hubungan nasab, maka timbulah hak dan kewajiban antara orang yang mempunyai hubungan nasab tersebut, yang mencakup hak-hak nasab dan hak-hak keperdataan. Hak-hak nasab, seperti hak saling mewarisi, hak menjadi wali nikah terhadap seorang anak perempuan ketika melangsungkan aqad nikah, hak seorang anak untuk menggunakan nama bapaknya sebagai bin atau binti di belakang namanya. ${ }^{20} \mathrm{Hak}-$

16 Tim Prima Pena, Kamus Ilmiah Populer, (Surabaya: Gitamedia Press, 2006), h. 332.

17 Departemen Pendidikan dan Kebudayaan, Kamus Besar Bahasa Indonesia, (Jakarta: Balai Pustaka, 1998), Cet. ke-1, h. 609.

${ }_{18}$ Ensiklopedi Islam, (Jakarta, Ikhtiar Baru Van Hoeve, 1990), Cet. ke-1, Jilid 4. h. 14.

${ }^{19}$ Ensiklopedi Hukum Islam, (Jakarta, Ikhtiar Van Hoeve, 2006), Cet. ke-7, jilid 4, h. 1304

${ }^{20}$ Dalam Alquran, Allah Swt melarang anak-anak angkat dipanggil dengan nama bapak angkatnya, tetapi hendaklah anak 
hak nasab semacam ini tidak dapat diperoleh kecuali sebagai konsekwensi pernikahan yang sah. Hak hak tersebut tidak dapat diperoleh, kecuali harus melalui pernikahan yang sah, sah menurut agama dan sah pula menurut hukum dan perundang-undangan.

Adapun hubungan perdata digunakan hanya terbatas pada hal-hal yang berkaitan dengan kepentingan si anak yang merupakan tugas orang tua dalam bidang kesejahteraan, biaya pendidikan, nafkah, perawatan dan pengasuhan atau pemeliharaan anak. Tugas-tugas tersebut dapat juga dialihkan dari orang yang mempunyai hubungan nasabpertalian darah kepada orang lain. Dalam kasus pengangkatan anak misalnya, masalah nasab tidak boleh berubah, seperti wali nikah, hak saling mewarisi dan pemakaian nama bapak (bin atau binti) tidak boleh seorang anak dinisbahkan kepada orang lain yang bukan bapaknya. Adapun masalah keperdataan, seperti perawatan, nafkah hidup, biaya pendidikan anak, dan lain-lain, seorang anak angkat dapat memperolehnya dari siapa saja yang bersedia menjadikannya sebagai anak angkat. Dengan demikian, hubungan keperdataan tidak mencakup di dalamnya hubungan nasab.

Jika hubungan nasab tidak bisa terbentuk kecuali melalui pintu pernikahan yang sah, maka hubungan keperdataan bisa saja terbentuk tanpa melalui pernikahan yang sah, dan bisa dipindahkan kepada orang lain selain orang tua kandungnya, misalnya dalam kasus anak angkat.

\section{Urgensi Nasab Dalam Memelihara Keturunan}

Di antara tujuan disyariatkannya ajaran hukum Islam adalah untuk memelihara dan menjaga keturunan atau nasab. ${ }^{21}$ Nasab merupakan salah satu pondasi dasar yang kokoh dalam

angkat itu dipanggil dengan memakai nama bapak kandungnya (Q.S. Al-Ahzab[33]:5). Ketika Rasulullah saw menjadikan Zaid bin Haritsah sebagai anak angkatnya, kemudian beliau memanggil Zaid bin Muhammad, hal ini kemudian ditegur oleh Allah Swt bahwa Zaid harus dipanggil dengan memakai nama bapaknya yaitu Haritsah.

${ }^{21}$ Al-Syathibi, Al-Muwafaqat fi Ushul al-Ahkam, (Mesir: Dar al-Fikr, 1341.H), jilid 2, h. 5 membina suatu kehidupan rumah tangga yang bersifat mengikat antar pribadi berdasarkan kesatuan darah. ${ }^{22}$ Nasab tidak dapat terbentuk tanpa adanya pernikahan yang sah.

Dalam teori maqashid syari ah, memelihara keturunan (hifzh al-nasl), merupakan cara untuk memelihara keturunan yang sah. ${ }^{23}$ Karena itu, konsep nasab dalam Islam sangat jelas, karena harus dimulai dari proses perkawinan yang sah, ia tidak mungkin dapat ditetapkan melalui perzinaan, karena perzinaan merupakan sebagai perbuatan tercela yang akan melahirkan anak yang tidak memiliki nasab yang jelas. Oleh sebab itu, nasab dalam Islam sangat penting, karena nasab akan bersangkut paut dengan permasalahan lain yang lebih luas, misalnya berhubungan dengan hak hak waris dan wali, serta hak hak keperdataan lainya.

Dengan demikian, membahas mengenai urgensi nasab dalam Islam tidak bisa lepas dari uraian mengenai pernikahan, karena hanya hanya melalui pernikahanlah terbentuknya nasab. Pernikahan adalah satu satunya pintu dalam rangka mewujudkan keberlangsungan nasab yang sah dalam Islam. Permasalahan yang sering muncul adalah adanya perbedaan dalam tujuan pernikahan antara hukum perdata dengan Undang-Undang Perkawinan, termasuk perbedaan pengertian tentang perkawinan.

Perbedaan pengertian tentang perkawinan menurut KUH Perdata dan menurut UndangUndang Perkawinan dapat dilihat antara lain, perkawinan menurut KUH Perdata hanya sebagai perikatan perdata sebagaimana ditentukan di dalam pasal 26, sedangkan perkawinan menurut Undang-Undang Perkawinantidak hanya sebagai ikatan perdata tetapi juga merupakan perikatan keagamaan yang kuat (mitsaqon gholidhon), hal ini dapat dilihat dari tujuan perkawinan yang dikemukakan dalam pasal 1 Undang-Undang Nomor 1 Tahun 1974 tentang

${ }^{22}$ Nurul Irfan, Nasab dan Status Anak Dalam Hukum Islam,(Jakarta: Penerbit Amzah, 2012), h. 13

${ }^{23}$ Fathurahman Djamil, Filsafat Hukum Islam, (Jakarta: Logos Wacana Ilmu, 2012), h. 130 
Perkawinan, bahwa perkawinan itu bertujuan untuk membentuk keluarga (rumah tangga) yang bahagia dan kekal berdasarkan Ketuhanan Yang Maha Esa. Kalimat itu tidak ada sama sekali di KUH Perdata (BW). ${ }^{24}$ Dari sini dapat kita lihat perbedaan yang nyata antara perkawinan dalam Undang-Undang Nomor 1 Tahun 1974 dengan Hukum Perdata.

Kedudukan hukum anak menjadi sangat penting, baik dalam kacamata kehidupan sosial maupun dalam hal pembagian warisan apabila orang tuanya meninggal dunia. Kedudukan anak sah tentunya sangat urgen, terlebih-lebih kalau dibandingkan dengan anak luar nikah. Kedudukan anak tersebut, anak sah atau anak luar nikah, sangat ditentukan oleh status perkawinan orang tua yang melahirkannya. Sesuai dengan ketentuan Pasal 42 Undang-Undang Perkawinan dinyatakan, bahwa anak sah adalah anak yang dilahirkan dalam atau sebagai akibat perkawinan yang sah. Jelas merupakan penegasan pasal tersebut tentang bagaimana keterkaitan lembaga perkawinan dengan posisi anak di dalam hukum untuk digolongkan sebagai anak sah atau anak luar nikah. Jadi sebuah perkawinan itu sangat menentukan kedudukan anak yang dilahirkan yang pada akhirnya akan menyangkut pula hak hak nasab dan keperdataannya.

Perkawinan memang merupakan suatu perekat dari hubungan hukum yang dilakukan oleh dua orang manusia yang berlainan jenis kelamin. Perbuatan hukum kawin, akan menimbulkan akibat-akibat hukum yang panjang. Hal ini seperti yang dinyatakan oleh J. Satrio dalam salah satu karyanya menyatakan bahwa perkawinan mempunyai akibat hukum tidak hanya terhadap diri pribadi mereka-mereka yang melangsungkan pernikahan, hak dan kewajiban yang mengikat pribadi suami-isteri dan biasanya hak dan kewajiban inilah yang pertama-tama terfikir kalau kita bicara tentang hak dan kewajiban suami isteri tetapi lebih dari

${ }^{24}$ Hilman Hadikusuma, Hukum Perkawinan Indonesia Menurut Perundangan, Hukum Adat, Hukum Agama, (Bandung: Mandar Maju, 2003), h. 8. itu, mempunyai akibat hukum pula terhadap harta suami isteri tersebut. ${ }^{25}$

Dalam membahas mengenai kedudukan hukum anak luar nikah di dalam suatu kelompok sosial, tidak bisa dilepaskan dari nuansa agama yang dianut oleh Undang-Undang Perkawinan, hal ini dapat dilihat dari besarnya pengaruh agama khususnya agama Islam dalam UndangUndang Perkawinan. Setiap peristiwa hukum perkawinan mesti tidak bisa dilepaskan dari rukun dan syarat perkawinan, baik yang terdapat dalam hukum agama maupun perundang undangan.

Rukun adalah unsur yang melekat pada peristiwa hukum atau perbuatan hukum (misalnya akad perkawinan), baik dari segi para subyek hukum maupun obyek hukum yang merupakan bagian dari perbuatan hukum atau peristiwa hukum (akad nikah) ketika peristiwa hukum (akad nikah) tersebut berlangsung. Rukun menentukan sah atau tidak sahnya suatu perbuatan atau peristiwa hukum. Jika salah satu rukun dalam peristiwa atau perbuatan hukum itu tidak dipenuhi berakibat perbuatan hukum atau peristiwa hukum tersebut tidak sah atau statusnya batal demi hukum. ${ }^{26}$

\section{Anak Luar Nikah dalam Islam}

Berbicara mengenai anak luar nikah, berarti juga berbicara mengenai asal usul anak. Penetapan asal usul anak dalam perspektif hukum Islam memiliki arti yang sangat penting, karena dengan penetapan itulah dapat diketahui hubungan nasab antara anak dengan ayahnya. Kendatipun pada hakikatnya setiap anak yang lahir berasal dari sperma seorang laki laki dan sejatinya harus menjadi ayahnya, namun hukum Islam memberikan ketentuan lain. ${ }^{27}$

Dalam kajian hukum Islam, untuk dapat

25 J.Satrio, Hukum Harta Perkawinan, (Bandung : Citra Aditya Bakti, 1991), h. 5

${ }^{26}$ Neng Djubaidah, $O p$ Cit.,h. 90.

${ }_{27}$ Amiur Nuruddin dan Azhari Akmal Tarigan, Hukum Perdata Islam di Indonesia, studi Kritis perkembangan Hukum Islam dari Fikih, UU Nomor 1 Tahun 1974 sampai KHI, (Kencana Prenada Media Group, Jakarta, 2012), h. 276. 
menetapkan seorang anak yang dilahirkan termasuk kategori anak luar nikah, atau anak sah, harus melihat kepada paling tidak tiga aspek. ${ }^{28}$ Pertama, apabila janin tersebut dibenihkan dalam pernikahan yang sah atau tidak sah. Jika janin tersebut dibenihkan dalam pernikahan yang sah meskipun dilahirkan setelah pernikahan bubar karena suami meninggal atau karena penceraian, maka anak tersebut dinyatakan sebagai anak yang sah, dan nasabnya adalah kepada ibu bapaknya. Tetapi jika janin tersebut dibenihkan di luar nikah yang sah, maka anak tersebut dinyatakan sebagai anak tidak sah atau anak luar nikah.

Kedua,apabila anak tersebut selama dalam kandungan memenuhi batas minimal masa kehamilan atau tidak. Dalam Islam di sebutkan bahwa masa kehamilan dan menyusui adalah minimal tiga puluh bulan, dengan ketentuan bahwa masa menyusui yang ideal adalah dua tahun penuh (dua puluh empat bulan), sehingga dari ketentuan tersebut dapat diketahui bahwa batas minimal kehamilan adalah enam bulan dari pernikahan. Jadi, jika seorang anak lahir setelah enam bulan dari pernikahan, maka anak tersebut secara syar'i dipandang sebagai anak yang sah dari suami isteri tersebut, tetapi jika anak tersebut dilahirkan dalam keadaan normal sebelum enam bulan dari pernikahan, maka anak tersebut harus dinyatakan sebagai anak zina, karena dapat dipastikan bahwa anak itu telah dibenihkan (fertilisasi) sebelum pernikahan dilaksanakan;

Ketiga, kelahiran tersebut tidak melampaui masa dua tahun sejak suami isteri itu bercerai atau suaminya mafqud (hilang berdasarkan keputusan pengadilan), maka anak yang lahir itu adalah anak yang sah, tetapi jika anak itu lahir melampaui masa dua tahun dari putusnya pernikahan atau sejak dinyatakannya suami hilang, maka status anak tersebut adalah anak tidak sah.

Dalam pandangan Islam, setiap anak yang dibenihkan di luar nikah, meskipun nantinya

${ }^{28}$ Nurul Irfan, Nasab dan..., h. 1. dilahirkan dalam nikah yang sah tetap dipandang sebagai anak zina atau anak luar nikah, dan silsilah keturunannya (nasab)nya hanya dihubungkan dengan ibu yang melahirkannya dan keluarga ibunya. ${ }^{29}$

Dalam konteks ini, nampaknya ketentuan Pasal 43 ayat (1) Undang-Undang Perkawinan Nomor 1 Tahun 1974 tidak dapat secara langsung dikompromikan dengan pandangan Islam diatas, sebab terdapat nilai-nilai yang tidak sejalan antara dua ketentuan tersebut. Sedangkan dalam KUHPerdata mengenai anak yang lahir di luar perkawinan adalah anak yang dilahirkan dari seorang perempuan yang tidak dalam ikatan perkawinan berbeda dengan anak zina adalah anak yang lahir dari seorang wanita tetapi laki laki yang menghamili wanita tersebut sudah beristeri secara sah. ${ }^{30}$

Menurut Amiur Nuruddin dan Azhar Akmal Tarigan, seorang anak dapat dikatakan sah memiliki hubungan nasab dengan ayahnya jika terlahir dari perkawinan yang sah, sebaliknya anak yang lahir diluar perkawinan yang sah, tidak dapat disebut dengan anak yang sah, biasa disebut dengan anak zina atau anak di luar perkawinan yang sah. ${ }^{31}$ Dengan demikian, yang dimaksud dengan anak luar nikah adalah anak yang dilahirkan di luar perkawinan yang sah.

Menurut Anshary, anak luar nikah adalah anak yang dilahirkan oleh seorang ibu, tetapi ia tidak dibenihkan oleh seorang laki laki yang terikat hubungan perkawinan sah dengan wanita lain, dan tidak pula termasuk kategori anak sumbang atau anak zina. ${ }^{32}$ Jadi anak luar nikah adalah anak yang dilahirkan dari hubungan seksual seorang laki laki dengan seorang perempuan yang keduanya tidak terikat dengan perkawinan yang sah. Anak yang lahir di luar nikah (anak luar nikah) dalam BW dinamakan natuurlijke kind.

${ }^{29}$ Lihat Q.S. Al-Mujadalah ayat 2: "Sesungguhnya Ibu-ibu mereka tidak lain hanyalah wanita yang melahirkan mereka".

${ }^{30}$ Mulyadi, Kedudukan Hukum Anak Luar Kawin Yang Diakui, Cakrawala11, No. 1 (27 Juni 2016), h. 2.

${ }^{31}$ Departemen Agama RI, Analisa Hukum..., h. 412.

32 Anshary, Kedudukan Anak Dalam Perspektif Hukum Islam dan Hukum Nasional, (Bandung: Mandar Maju, 2014). h. 59 
Seorang anak dilahirkan melalui proses yang panjang, mulai dari adanya pertemuan biologis antara benih dari seorang laki laki dan sel telur seorang perempuan, sampai terjadinya proses kehamilan hingga lahirnya seorang anak. Menurut Witanto Jika proses yang dilalui tidak sah, baik menurut hukum agama maupun menurut hukum negara, maka ketika lahir si anak akan menyandang prediket sebagai anak tidak sah (anak luar kawin). ${ }^{33}$

Memahami pendapat Witanto di atas, jika proses yang dilalui tidak sah, maka proses tersebut bukan saja proses pernikahannya yang tidak sah, melainkan prosesnya yang tidak dimulai dengan pernikahan, juga melahirkan anak luar kawin. Proses yang tidak dimulai dengan perkawinan, dalam terminologi Islam termasuk zina.

I Nyoman Sujana menguraikan sebab dan latar belakang terjadinya anak luar nikah timbul antara lain sebagai berikut: ${ }^{34}$

a. Anak yang dilahirkan oleh seorang wanita tetapi wanita itu tidak mempunyai ikatan perkawinan dengan pria yang menghamilinya.

b. Anak yang dilahirkan dari seorang wanita, kelahiran tersebut diketahui dan dikehendaki oleh salah satu atau ibu bapaknya, hanya saja salah satu atau kedua orang tuanya masih terikat dengan perkawinan lain.

c. Anak yang lahir dari seorang wanita dalam masa iddah perceraian tetapi anak yang dilahirkan itu hasil hubungan dengan pria yang bukan suaminya.

d. Anak yang lahir dari seorang wanita yang ditinggal suaminya lebih dari 300 hari, anak tersebut tidak diakui suaminya sebagai anak yang sah.

e. Anak yang lahir dari seorang wanita, tetapi anak tersebut tidak mengetahui siapa orang tuanya.

f. Anak yang lahir dari perkawinan yang tidak tercatat di Kantor Catatan Sipil atau Kantor Urusan Agama.

${ }^{33}$ Witanto, Hukum Keluarga, Hak dan Kedudukan Anak Luar Kawin, (Jakarta: Prestasi Pustaka Publiser, 2012), h. 7

${ }^{34}$ I Nyoman Sujana, Op. Cit, h. 64 g. Anak yang lahir dari perkawinan secara adat tidak dilaksanakan secara agama dan tidak tercatat di Kantor Catatan Sipil atau Kantor Urusan Agama.

Berdasarkan beberapa pendapat di atas, dapat disimpulkan bahwa sebagian pendapat menyamakan antara anak luar nikah dengan anak zina, antara lain I Nyoman Sujana dan Witanto, sedangkan Nurul Irfan membedakan antara anak luar nikah dengan anak zina. Menurut Nurul Irfan, zina adalah hubungan badan antara laki laki dan perempuan di luar nikah. ${ }^{35}$ Anak yang lahir dari hubungan luar nikah adalah anak zina. Sedangkan anak luar nikah adalah anak yang lahir dari pernikahan yang tidak sah. ${ }^{36}$

Dalam memahami anak luar nikah, memang ada perbedaan persepsi antara hukum Islam dan hukum positif di Indonesia, terutama $\mathrm{KUH}$ Perdata tentang pengertian anak luar nikah (natuurlijke kind). ${ }^{37}$

Dalam Islam, suatu pernikahan dikatakan sah, apabila telah memenuhi rukun-rukun nikah, yakni wali nikah, dua orang saksi nikah, dan ijab-qabul (aqad), serta tidak adanya halangan hukum. ${ }^{38}$ Hubungan biologis yang dilakukan setelah aqad nikah yang telah memenuhi rukunrukun nikah adalah hubungan biologis yang halal, dan anak yang dilahirkan sebagai akibat dari pernikahan semacam ini secara syar'i dinyatakan sebagai anak yang sah. ${ }^{39}$

Menurut ketentuan Pasal 272 KUH Perdata, anak luar nikah ini dapat berstatus sebagai anak sah, jika ibu yang melahirkan dan laki-laki yang menghamili ibu itu menikah, dan sebelum melangsungkan pernikahan keduanya telah mengakui bahwa anak itu adalah anak mereka berdua, atau pengakuan itu dilakukan dalam akta nikah mereka. Jadi anak luar nikah dapat berubah kedudukannya menjadi anak sah,

\footnotetext{
${ }^{35}$ Nurul Irfan, Op. Cit, h. 114

${ }^{36}$ D.Y. Witanto, Op. Cit, h. 30

${ }^{37}$ Anshary, Op. Cit., h. 54.

${ }^{38}$ Anshary, Op. Cit., h. 56.

${ }^{39}$ Ibid.
} 
apabila pasangan suami isteri itu mengakuinya sebagai anaknya. Tetapi jika anak luar nikah itu tidak diakui oleh pasangan suami isteri itu, maka kedudukannya adalah sebagai anak zina atau anak sumbang.

Anak luar nikah (natuurlijke kind, dalam Islam disebut anak thabiiy) adalah anak yang dilahirkan di luar pernikahan dan hanya memiliki hubungan keperdataan dengan ibunya saja. Artinya, anak yang dibenihkan dan dilahirkan di luar pernikahan yang sah, disebut anak luar nikah dan hanya mempunyai hubungan keperdataan dengan ibu yang melahirkannya dan keluarga ibunya.

Dalam pandangan Islam, para Ulama sepakat mengatakan bahwa perzinaan bukan penyebab timbulnya nasab anak dengan ayah, sehingga anak zina tidak boleh dihubungkan dengan nasab ayahnya, meskipun secara biologis berasal dari benih laki laki yang menzinai ibunya. Oleh sebab itu, anak yang dilahirkan di luar pernikahan yang sah tidak mempunyai hubungan nasab dengan bapak biologisnya, meskipun dimungkinkan adanya hubungan perdata dengan bapak biologisnya.

Dengan demikian, ketentuan terhadap nasab anak luar nikah, tidak ada pilihan lain dalam pandangan Islam, kecuali hanya dinasabkan kepada ibunya dan keluarga ibunya, adapun kepada bapaknya, sekalipun memiliki hubungan darah, tetap tidak dapa dinasabkan kepada bapaknya. Meskipun demikian, kemungkinan untuk memiliki hubungan perdata dengan bapak biologisnya dapat dimungkinkan, antara lain melalui pengakuan, karena beban dan tanggungjawab tidak boleh hanya dipikul oleh ibunya, melainkan juga oleh bapak bilogisnya.

Anak yang dilahirkan dari perkawinan siri, yakni pernikahan yang memenuhi ketentuan agama, namun tidak dicatatkan, sehingga tidak memenuhi ketentuan undang-undang. Meskipun secara agama diakui sebagai anak sah, akan tetapi oleh karena perkawinan orang tuanya tidak dicatatkan, maka anak tersebut dilihat dari kacamata Undang-Undang Perkawinan, anak tersebut merupakan anak luar nikah, sehingga anak ini hanya mempunyai hubungan keperdataan dengan ibu dan keluarga ibunya.

\section{Kedudukan Hukum Anak Luar Nikah}

Sehubungan kedudukan anak luar nikah yang lahir dari perkawinan siri ini hanya mempunyai hubungan keperdataa dengan ibu dan keluarga ibunya saja, maka anak luar nikah dari perkawinan siri ini tidak memperoleh hak-haknya secara maksimal di negara yang berdasarkan atas hukum. Bahwa mengingat Indonesia adalah Negara yang menganut Negara kesejahteraan, maka di dalam masalah ini, seiring dengan pendapat dari W. Friedman yang menyebutkan bahwa Negara yang menaganut konsep Negara Kesejahteraan dapat mengembang 4 (empat) fungsi, yaitu:

1. The state as provider (negara sebagai pelayan)

2. The state as regulator (negara sebagai pengatur)

3. The state as enterpreneur (negara sebagai wirusahan), and

4. The state as umpire (negara sebagai wasit). ${ }^{40}$

Negara harus memiliki fungsi pelayanan kepada masyarakat hendaknya memberikan perlindungan hukum terhadapa hak-hak normatif anak luar nikah ini. Di samping itu, negara yang mempunyai kewenangan untuk mengatur masyarakat melalui penciptaan peraturan perundang-undangan yang mempunyai kekuatan memaksa, maka sudah sepatutunya pula negara dalam hal ini pemerintah segera untuk menerbitkan/mengeluarkan peraturan pemerintah yang mengatur mengenai kedudukan anak luar nikah beserta hak-haknya sebagai generasi penerus bangsa. Karena di dalam Undang-Undang Perkawinan sebagaimana diatur didalam ketentuan pasal 43 ayat (2) ditentukan bahwa kedudukan anak luar nikah selanjutnya akan diatur dalam peraturan pemerintah, namun setelah berlaku hampir lima puluh tahun (setengah abad) sejak diundangkan ternyata peraturan pemerintah yang dijanjikan oleh pembentuk Undang-undang ternyata sampai saat ini belum

${ }^{40}$ W. Friedman, The State and The Rule of Law $n$ A Mixed Economy, (London: Steven \& Son, 1971), h. 5. 
lahir, sehingga perlindungan terhadap anak luar nikah baru berjalan setengah bagian saja yaitu bagian dari ibu dan keluarga ibunya saja, sedangkan peraturan anak luar nikah dalam hubungan dengan ayah biologisnya sampai saat ini belum ada. Sehingga secara yuridis perlindunga hukum terhadap anak luar nikah dari perkawinan siri ini masih sangat lemah, karena belum diatur secara utuh dan lengkap.

Menurut konsep Negara kesejahteraan, tujuan negara adalah untuk kesejahteraan umum, yaitu suatu konsep yang menempatkan peran negara dalam setiap aspek kehidupan rakyatnya demi terwujudnya kesejahteraan sosial bagi seluruh rakyat. ${ }^{41}$

Teori negara kesejahteraaan sangat mendukung adanya sanksi tentang pelanggaran salah satu rukun nikah antara lain tidak dicatat dan tidak mempunyai wali. Hal ini mendukung terwujudnya kesejahteraan umum dan kemakmuran bagi seluruh rakyat Indonesia melalui pengaturan perkawinan sebagaimana diamanatkan dalam Undang-Undang Perkawinan dan Kompilasi Hukum Islam (KHI).

Secara hukum, anak-anak yang berasal dari perkawinan yang tidak dicatatkan, kelahirannya tidak dicatatkan pula secara hukum. Jika kelahiran anak-anak tidak dapat dicatatkan secara hukum, berarti telah terdapat pelanggaran terhadap hak-hak asasi manusia (Konvensi Hak Anak).Dengan demikian anak-anak tersebut menjadi mempunyai status sebagai anak yang lahir di luar perkawinan atau anak luar nikah, yang secara hukum berkedudukan sebagai anak tidak sah dan tidak mempunyai hubungan perdata dengan ayah biologisnya, namun hanya mempunyai hubungan perdata dengan ibu dan keluarga ibunya saja.

Antara nasab dan hubungan keperdataan harus dipahami secara berbeda, nasab adalah hubungan darah yang memiliki implikasi lebih

${ }^{41}$ Mustamin Dg.Matutu, Selayang Pandang Tentang Perkembangan Tipe-tipe Negara Modern, (Ujung Pandang: Fakultas Hukum dan Pengetahuan Mayarakat, Universitas Hasanuddin, 2001), h.15. luas, meliputi hubungan keperdataan serta hak hak dan kewajiban waris mewarisi serta menjadi wali, sedangkan hubungan kerdataan hanya berupa hak dan kewajiban antara kedua belah pihak yang harus dipenuhi, yang berimplikasi hanya sebatas memberikan nafkah, melindungi serta hak hak kewajiban lainya.

Nasab anak dari anak luar nikah yakni hasil nikah siri/tidak tercatat (memenuhi ketentuan pasal 1 ayat (1) tetapi tidak memenuhi ayat (2) Undang-Undang Nomor 1 Tahun 1974 tentang Perkawinan), maka implikasinya memiliki hubungan nasab dan hubungan keperdataan juga termasuk hak waris mewarisi, menjadi wali nikah serta kebolehan menggunakan bin atau binti di belakang namanya. Sedangkan anak tidak sah, yakni anak zina (tidak memenui ketentuan pasal 2 ayat (1) dan ayat (2) Undang-Undang Nomor 1 Tahun 1974 tentang Perkawinan, maka implikasinya hanya memiliki hubungan nasab dengan ibunya, meskipun dimungkinkan memilikihubungan perdata dengan bapak bilogisnya.

Meskipun ada persoalan yang sulit dikompromikan antara hubungan nasab dengan hubungan perdata dalam Islam dan UndangUndang Nomor 1 Tahun 1974, di satu pihak, hukum Islam menghendaki dibedakannya dua istilah diatas yakni hubungan nasab dan hubungan perdata, yang keduanya membawa akibat hukum yang berbeda. Di sisi lain, Undang-Undang Perkawinan Nomor 1 Tahun 1974, tidak membedakan dua istilah tersebut.

Dalam perspektif Islam maupun perundang undangan, memang tidak ditemukan secara spesifik pengertian tentang anak tanpa nikah, akan tetapi jika mengacu pada peraturan perundangan-undangan dapat ditarik pemahaman bahwa yang dimaksud dengan anak tanpa nikah adalah anak yang lahir tanpa adanya pernikahan/ perkawinan kedua orang tuanya, yakni anak zina (tidak memenuhi pasal 2 ayat (1) dan ayat (2) Undang Undang Nomor 1 Tahun 1974 tentang Perkawinan).

Anak tanpa nikah adalah anak yang dilahir- 
kan dari seorang perempuan yang tidak pernah melakukan pernikahan dengan laki laki yang menghamilinya. Akibat dari lahirnya anak dari perempuan tanpa ikatan perkawinan dengan laki laki yang menghamilinya, maka disebut anak zina.

Kata zina secara etimologi adalah bentuk masdar dari kata kerja يزن - زيز yang berarti berbut jahat. ${ }^{42}$ Sedangkan secara terminologi zina berarti hubungan seksual antara seorang laki dengan seorang perempuan melalui vagina bukan dalam akad pernikahan atau yang menyerupai akad ini. Zina juga dapat didefinisikan sebagai hubungan seksual antara seorang laki laki dengan seorang wanita yang tidak atau belum diikat oleh suatu perkawinan tanpa disertai unsur keraguan dalam hubungan seksual tersebut dan tidak ada hubungan pemilikan, seperti tuan dan hamba sahaya wanita. ${ }^{43}$ Khusus kepemilikan tuan terhadap hamba sahaya yang wanita dizaman sekarang sudah tidak ada lagi, maka dalam hal ini hakumnya tidak berlaku lagi. Perbuatan zina melahirkan anak tidak sah, sedangkan pernikahan yang tidak sah melahirkan anak luar nikah.

Berbeda dengan prinsip hukum perdata barat, dalam Islam zina tidak mempersoalkan salah satu atau kedua orang tuanya terikat perkawinan dengan yang lain atau tidak, sepanjang hubungan seksual tersebut dilakukan tanpa ikatan perkawinan, maka termasuk zina. Anak yang lahir akibat perbuatan zina, digolongkan anak tidak sah.

Adapun hubungan biologis yang dilakukan tanpa melalui akad nikah, maka disebut dengan perzinaan, dan anak yang lahir akibat dari hubungan biologis tersebut di sebut dengan anak zina atau anak tanpan ikah, meskipun anak tersebut dilahirkan dalam pernikahan yang sah karena ibu yang melahirkan anak tersebut dengan laki-laki yang menghamili ibunya (bapak biologis) kemudian melangsungkan pernikahan yang sah. ${ }^{44}$

\footnotetext{
${ }^{42}$ Luis Ma'luf, Al-Munjid fi Al-Lughah wa Al-A'lam, h. 308

43 Wahbah Al-Zuhaili, Al-Figh Al Islami wa Adillatuh, (Damaskus: Dar al-Fikr, 1987), Cetakan pertama Jilid 6, h. 109

${ }^{44}$ Wahbah Al-Zuhaili, Al Figh Al Islami..., h. 109
}

Dalam KUH Perdata, tidak semua hubungan biologis yang dilakukan di luar pernikahan dipandang sebagai perbuatan zina, karena perzinaan dalam persepsi KUH Perdata memiliki arti tersendiri.

Menurut pasal 284 KUH Pidana, seseorang dikatakan berbuat zina (overspel) apabila orang itu ketika melakukan hubungan seksual di luar pernikahan yang sah atau pasangan yang melakukan perzinaan itu dengannya terikat hubungan pernikahan sah dengan orang lain. Artinya, jika seseorang laki-laki melakukan hubungan seksual dengan seorang perempuan di luar nikah, maka perbuatannya itu baru dipandang sebagai perbuatan perzinaan apabila salah seorang atau kedua pelaku pada saat melakukan hubungan seksual terikat pernikahan sah dengan orang lain, sebagaimana diatur dalam Pasal 27 KUH Perdata. Akan tetapi, jika kedua pelaku hubungan seksual itu berstatus lajang, maka KUHP tidak mengaturnya. ${ }^{45}$

Pasal 285 KUHP mengatur: Barang siapa dengan kekerasan atau ancaman kekerasan memaksa seorang wanita bersetubuh dengan dia diluar pernikahan, di ancam dengan pidana.... ${ }^{46}$ Pasal ini memberikan signal bahwa jika hubungan seksual di luar nikah di lakukan dengan tanpa kekerasan atau paksaan, artinya hubungan seksual diluar nikah yang dilakukan dengan dasar suka sama suka, maka hal itu bukan termasuk kriteria perbuatan zina.

Pasal 286 KUHP mengatur, Barang siapa bersetubuh dengan seorang wanita diluar pernikahan, padahal diketahui bahwa wanita itu dalam keadaan pingsan atau tidak berdaya, di ancam dengan pidana. Dari bunyi pasal ini dapat dipahami bahwa jika hubungan seksual diluar pernikahan dengan orang yang sehat normal, tidak pingsan, maka hubungan seksual tersebut bukan merupakan perbuatan zina.

Pasal 287 KUHP mengatur, Barang siapa ber-

\footnotetext{
${ }^{45}$ Soesilo, dan Pramudji R, Kitab undang-undang hukum perdata, diterjemahkan dari Burgerlijk Wetboek, (Renerbit Rhedbook Publisher, 2008), h. 285.

${ }^{46}$ Soesilo, dan Pramudji R, Op, Cit,. 286.
} 
setubuh dengan seorang wanita di luar pernikahan, padahal diketahuinya atau sepatutnya harus diduga bahwa umurnya belum lima belas tahun, atau kalau umurnya tidak jelas, bahwa belum waktunya untuk dinikah, diancam dengan pidana...... ${ }^{47}$ Pasal ini mengatur bahwa jika hubungan seksual dilakukan di luar nikah dengan wanita yang belum berumur lima belas tahun, di pidana. Artinya, jika hubungan seksual di luar nikah itu dilakukan dengan seorang wanita yang telah berumur lima belas tahun atau lebih, maka hubungan seksual itu tidak dapat dipidana karena bukan perbuatan zina.

Dari bunyi pasal-pasal KUHP di atas, dapat dimengerti bahwa meskipun hubungan seksual dilakukan di luar nikah, hal itu tidak dapat di kategorikan sebagai perbuatan zina, jika memenuhi empat kriteria berikut ini, yaitu hubungan seksual itu dilakukan oleh dua orang yang keduanya berstatus lajang, dilakukan dengan dasar suka sama suka, dilakukan dengan wanita yang telah berumur lima belas tahun ke atas, dilakukan dengan orang yang sadar (tidak sedang dalam keadaan pingsan). ${ }^{48}$

Jadi, yang dimaksud perbuatan zina menurut KUHP adalah hubungan seksual yang dilakukan oleh dua orang, laki-laki dan perempuan di luar nikah, yang kedua-duanya atau salah satu dari keduanya pada saat melakukan hubungan seksual itu terikat hubungan pernikahan dengan orang lain. Dengan kata lain, seorang laki-laki yang terikat pernikahan dengan seorang isteri, atau seorang perempuan yang terikat pernikahan dengan seorang suami, apabila mereka melakukan hubungan seksual, atau hanya salah satu dari mereka saja yang terikat hubungan pernikahan dengan orang lain sedangkan yang lainnya masih lajang, melakukan hubungan seksual, perbuatan itu dinyatakan sebagai perbuatan perzinaan. ${ }^{49}$

Dalam pasal 272 KUH Perdata, ${ }^{50}$ dibedakan antara anak zina dengan anak sumbang dan anak

\footnotetext{
${ }^{47}$ Soesilo, dan Pramudji R,Op. Cit,. 287

${ }^{48}$ Anshary Op. Cit., h. 58.

${ }^{49}$ Anshary, Op. Cit., h. 56.

${ }^{50}$ Soesilo, dan Pramudji R, Op. Cit, h. 68.
}

luar nikah. Anak zina adalah anak yang dilahirkan dari akibat hubungan seksual antara dua orang (laki-laki dan perempuan) yang bukan suami isteri, dan salah satu dari keduanya atau keduanya masih terikat hubungan pernikahan dengan orang lain. Anak sumbang adalah anak yang dilahirkan sebagai akibat hubungan seksual antara dua orang yang mempunyai hubungan darah yang dekat sehingga antara mereka dilarang oleh undangundang untuk melangsungkan pernikahan. ${ }^{51}$ Anak luar nikah adalah anak yang dilahirkan oleh seorang ibu, tetapi ia tidak dibenihkan oleh seorang laki-laki yang terikat hubungan pernikahan yang sah dengan wanita lain, dan tidak pula termasuk kategori anak sumbang atau anak zina. Jadi anak luar nikah, adalah anak yang lahir dari hubungan seksual seorang laki-laki dan seorang perempuan yang kedunya berstatus lajang, dan dilakukan dengan cara suka sama suka, dan telah berusia lima belas tahun atau lebih. Anak yang lahir di luar nikah (anak luar nikah), dalam BW (burgerlijke Wetboek) dinamakan natuurlijke kind. ${ }^{52}$

Dalam hukum Islam berpandangan bahwa setiap hubungan seksual di luar pernikahan yang dilakukan oleh seseorang yang masih single atau telah bersuami-isteri, yang menyebabkan kehamilan ataupun tidak, adalah zina. Dan perbuatan zina merupakan dosa besar. Pengertian zina yang disepakati oleh para ulama adalah, persetubuhan yang dilakukan oleh seorang lakilaki dan perempuan diluar nikah. ${ }^{53}$ Adapun anak yang dilahirkan dari hubungan biologis di luar nikah disebut dengan anak zina. ${ }^{54}$ Dalam termonologi undang undang anak zina disebut anak tanpa nikah.

\section{Kedudukan Hukum Anak Tanpa Nikah}

Kedudukan hukum anak yang lahir tanpa adanya pernikahan, sebagaimana penjelasan di atas, yakni anak yang lahir tanpa ikatan

51 Wirjono Prodjodikoro, Hukum Waris Di Indonesia, (Bandung: Penerbit Sumur, 1976), h. 158.

52 Wirjono Prodjodikoro, Hukum Waris..., h. 158.

53 Ibnu Rusyd, Bidayatul Mujtahid, Jilid 2, terjemahan, (Jakarta: Penerbit Pustaka Azzam, 2007), h. 875.

${ }^{54}$ Anshary, Op. Cit., h. 55. 
pernikahan antara perempuan dengan laki laki yang menghamilinya, memiliki konsekwensi hanya memiliki hubungan perdata dengan ibunya dan keluarga ibunya.

Dalam Pasal 289 KUH Perdata ${ }^{55}$ diatur bahwa anak zina dan anak sumbang tidak bisa memiliki hubungan nasab dan hubungan keperdataan dengan ibunya dan bapak biologisnya. Bila anak itu terpaksa disahkan pun tidak ada akibat hukumnya.

Pasal 283 KUH Perdata $^{56}$ menyebutkan bahwa Sekalian anak yang dibenihkan dalam zina ataupun dalam sumbang, sekali-kali tak boleh diakui, kecuali terhadap yang terakhir ini apa yang ditemukan dalam Pasal 273. Ketentuan Pasal 273 KUH Perdata ${ }^{57}$ berbunyi, Anak yang dilahirkan dari bapak dan ibu, antara siapa tanpa dispensasi Presiden, tak boleh diadakan pernikahan, tak dapat disahkan, melainkan dengan cara mengakuinya dalam akta pernikahan.

Berkaitan dengan kedudukan hukum anak yang lahir tanpa adanya pernikahan, yakni anak zina, maka anak tersebut kedudukannya sebagai anak tidak sah, dari konsep keperdataan ia hanya memiliki hubungan perdata dengan ibunya. Sehubungan dengan hal tersebut, maka hak haknya sebagai anak yang dilahirkan tanpa adanya perkawinan, mengacu pada Fatwa MUI Nomor 11 Tahun 2012, tentang Kedudukan anak zina dan perlakukan terhadapnya, yang pada intinya menentukan bahwa:

a. Anak hasil zina tidak memiliki hubungan nasab, wali nikah, waris dan nafkah dengan laki laki yang menyebabkan kelahirannya.

b. Anak hasil zina hanya memimilki nasab, waris dan nafkah dengan ibunya dan keluarga ibunya.

c. Anak hasil zina tidak menanggung dosa perzinaan yang dilakukan oleh orang yang menyebabkan kelahiranya,

\footnotetext{
${ }^{55}$ Soesilo dan Pramudji R, Op. Cit., h.69

${ }^{56}$ Ibid.

${ }^{57}$ Ibid.
}

d. Pezina dikenakan hukuman hadd oleh pihak yang berwenang, untuk kepentingan menjaga keturunan yang sah,

e. Pemerintah berwenang menjatuhkan hukuman tázir kepada laki laki pezina yang menyebabkan lahirnya anak dengan mewajibkannya untuk:

1. Mencukupi kebutuhan hidup anak tersebut;

2. Memberikan harta setelah ia meninggal melalui wasiat wajibah. ${ }^{58}$

f. Hukuman sebagaimana dimaksud nomor 5 bertujuan melindungi anak, bukan untuk mensahkan hubungan nasab antara anak tersebut dengan laki laki yang mengakibatkan kelahirannya. ${ }^{59}$

Dengan demikian, di sini jelas kedudukan hukum anak zina atau anak yang dilahirkan tanpa melalui pintu pernikahan, sebagai anak tidak sah, ia hanya memimiliki hubungan perdata dengan ibunya dan keluarga ibunya. Bagi laki laki yang menyebabkan kelahirannya dapat dikenakan hukuman tázir, dengan memberikan nafkah dan kebutuhan hidup, hukuman tersebut sermata mata untuk memberikan perlindungan terhadap anak, sehingga anak memperoleh jaminan kehidupan yang selayaknya. Hubungan perdata anak zina tidak menyebabkan hubungan nasab, tetapi mewajibkan orang tua biologisnya memberikan jaminan kehidupan bagi anaknya. Seandainya anak zina adalah seorang perempuan, apabila mau menikah, maka yang berhak menjadi wali adalah wali hakim, sedangkan orang tuanya, dalam hal ini bapak biologisnya berkewajiban menyelenggarakan walimahnya.

\section{Pustaka Acuan}

Ahmad Rofiq, Fiqih Mawaris, Jakarta: PT. Raja Grafindo Persada, 1998.

Atsqalany, Ibnu Hajar al-, Fathul Bari, Juz

${ }^{58}$ Dalam Islam sebab sebab menerima warisan antara lain, hubungan kekerabatan, perkawinan dan perbudakan. Libat. Sayid Sabiq, Fiqih Sunnah, (Beirut, Daarul Fikr, 1983), h. 350.

59 Lihat. Fatwa Majelis Ulama Indonesia Nomor 11 Tahun 2012 tentang Kedudukan anak zina dan perlakukan terhadapnya. 
9, Mesir: Pustaka al-Baby al-Halabi wa Auladuhu, t.th.

Ali, Ahmad, Menguak Teori Hukum (Legal Theori) dan Teori Peradilan (Judicialprudence) Termasuk Interpretasi Undang undang (Legisprudence), Jakarta : Kencana Prenada Media Group, 2012.

Ali, Muhammad Daud, Hukum Islam Pengantar Ilmu Hukum dan Tata Hukum Islam di Indonesia, Jakarta: Raja Grafindo Persada, 2004, Cet. ke-11.

Al-Maqdisi, Ibnu Qudamah, Al-Mughni, Beirut: Dar al-Fikr, t.th.

Al-Syathibi, Al-Muwafaqat fi Ushul al Ahkam, jilid III , Dar al-Fikr, t.th.

Amiur Nuruddin dan Azhari Akmal Tarigan, Hukum Perdata Islam di Indonesia, Studi Kritis Perkembangan Hukum Islam dari Fikih, Undang Undang Nomor 1 Tahun 1974 sampai KHI, Jakarta, Kencana Prenada Media Grup, 2004, Cet. ke-1.

Andiko, Toha, Ilmu QowaidulFiqhiyyah, Pandunan Praktis Dalam Merespon Problematika Hukum Islam Kontemporer, Jogyakarta : Penerbit Teras, 2011.

Anshary, Anshary, Kedudukan Anak Dalam PerspektifHukum Islam dan Hukum Nasional, Bandung: Mandar Maju, 2014.

Arto, Mukti, Pembaruan Hukum Islam Melalui Putusan Hakim, Jogyakarta, Pustaka Pelajar, 2015.

AW. Widjaja, Hukum Waris Indonesia, Bandung: PT.Citra aditya Bakti, 1991.

Bisri, Cik Hasan dkk, Kompilasi Hukum Islam dalam Sistem Hukum Nasional, Jakarta: Logos Wacana Ilmu, 1999.

Dahlan Abdul Aziz, Ensiklopedi Hukum Islam, Jakarta: Ichtiar baru Van Hoeve, 1997.

Departemen Agama RI, Analisa Hukum Islam Tentang Anak Luar Nikah, Direktorat Pembinaan Peradilan Agama, Dirjen Bimbagais, Departemen Agama, 2004.

Djubaidah, Neng, Pencatatan Perkawinan dan Perkawinan Tidak Tercatat Menurut Hukum Tertulis di Indonesia dan Hukum Islam, Jakarta: Sinar Grafika, 2010.
Effendi, Satria, Problematika Hukum Keluarga Islam Kontemporer, Analisis Yurisprudensi dengan Pendekatan Ushuliyah, Jakarta: Kerjasama UIN Jakarta dengan Balitbang Departemen Agama RI, 2010.

Ensiklopedi Hukum Islam, Jakarta; Ikhtiar Baru Van Hoeve, Cet ketujuh, Jilid 4, 2006.

Friedman, W., The State and The Rule of Law n A Mixed Economy, London: Steven \& Son, 1971.

Irfan, Nurul, Nasab dan Status Anak Dalam Hukum Islam, Jakarta: Penerbit Amzah, 2012.

J. Satrio, Hukum Keluarga Tentang Kedudukan Anak dalam Undang Undang, Bandung: PT Citra Aditia Bhakti, 2005.

Jaziri, Abdurrahman al-, al-Figh 'ala Madzahib al-Arba'ah, Beirut: Dar al-Fikr, 1986.

Jimly Asshiddiqie, Konstitusi dan Konstitualisme Indonesia, Sinar Grafika, Jakarta, 2011.

Kaharuddin, Nilai nilai Filosofi Perkawinan menurut Hukum Perkawinan Islam dan Undang Undang RI Nomor 1 Tahun 1974, Jakarta: Mitra Wacana Media, 2015

Khallaf, Abdul Wahhab, Kaedah Kaedah Hukum Islam, Ilmu Ushul al-Figh, Jakarta: PT Raja Grafindo Persada, 2002, Cet. ke-8.

Kharlie, Ahmad Tholabi, Hukum Keluarga Indonesia, Jakarta: Sinar Grafika, 2013.

M. Zein, Satria Effendi, Problematika Hukum Keluarga Islam Kontemporer, Jakarta: Prenada Media, 2005.

Mahkamah Agung RI, Himpunan Peraturan Perundang Undangan Tentang Peradilan Agama, Jakarta: Direktorat Jenderal Badan Peradilan Agama, 2010.

Mahkamah Agung RI, Yurisprudensi Mahkamah Agung RI, Jakarta: Mahkamah Agung RI, 2007.

Maraghi, Ahmad Mustafa al-, Tafsir Al-Maraghi, Jilid V, Terjemahan, Semarang: Penerbit Toha Putra, 1986.

Mardani, Hukum Keluarga Islam di Indonesia, Pranada Media Group, Jakarta 2016.

Mertokusumo, Sudikno, Hukum Acara Perdata Indonesia, Edisi Revisi Jogyakarta: Cahaya Atma Pustaka, 2013. 
Muthiah, Aulia, Hukum Islam, Dinamika Seputar Hukum Keluarga, Jogyakarta: Pustaka Baru Press, 2017

Nasution, Khoiruddin dkk., Hukum Perkawinan dan Kewarisan di Dunia Muslim Modern, Jogyakarta: ACAdeMIA, 2012.

Nasution, Khoiruddin, Pengantar Studi Islam, Jogyakarta: ACAdeMIA dan AZZAFA, Edisi Refisi, 2012.

Nasution, Muhammad Syukri Albani, Filsafat Hukum Islam, Jakarta :Raja Grafindo Persada, 2013.

Nata, Abudin, Metodologi Studi Islam, Jakarta: PT Raja Grafindo Persada, 2011. Cet. ke-12.

Nurul Hak, Implikasi Putusan Mahkamah Konstitusi Tentang Status Anak Luar Nikah terhadap Sistem Kewarisan Islam, Penelitian, DIPA IAIN Bengkulu, 2013.

Qomar, Nurul, Hak Azasi manusia dalam Negara Hukum Demokrasi (Human Rights in Democratiche Rechsstaat), Jakarta: Sinar Grafika, 2013.

Rusyd, Ibnu, Bidayatul Mujtahid, Jilid 2, Terjemahan, Jakarta: Pustaka Azzam, 2007.

Shihab, M. Quraish, Tafsir Al Misbah, Jakarta: Penerbit Lentera Hati, 2007.

Somad, Abd., Hukum Islam Penormaan Prinsip Syariah dalam Hukum Indonesia, Jakarta: Kencana Prenada Media Grup, 2010.

Sujana, I Nyoman, Kedudukan Anak Luar Kawin Dalam Perspektif Putusan Mahkamah Konstitusi Nomor 46/PUU-VIII/2010, Jogyakarta : Aswaja Pressindo, 2015.

Syahuri, Taufiqqurrahman, Legislasi Hukum Perkawinan Di Indonesia, Pro-Kontra Pembentukannya hingga Putusan Mahkamah Konstitusi, Jakarta: Kencana Prenada Media Group, 2013.

Syarifuddin Amir, Ushul Figh, Jakarta: Kencana Praneda Media Group, 2009.

Syarifuddin, Amir, Hukum Kewarisan Islam. Jakarta: Prenada Media, 2005, Cet. II.
Utsman, Sabian, Metodologi Penelitian Hukum Progresif, Jogyakarta: Pustaka Pelajar, 2014.

Witanto, D.Y., Hukum Keluarga, Hak dan Kedudukan Anak Luar Kawin, Pasca Keluarnya Putusan Mahkamah Konstitusi Tentang Uji Materiil UU Perkawinan, Jakarta: Prestasi Pustaka Publisher, 2012.

Zuhaili, Wahbah al-, Al-Figh Al Islami wa Adillatuh, Jilid VII, Damaskus: Dar al-Fikr, t.th.

Jurnal:

Mukhtaruddin Bahrum, Legalisasi Nikah Sirri Melalui Isbat Nikah Menurut Kompilasi Hukum Islam, (Jurnal Diskursus Islam, Vo.1, Nomor 2, Agustus 2013).

Muhammad Syahrul Khair, Analisis Yuridis Kedudukan Anak Luar Kawan pasca puitusan Mahkamah Konstitusi Nomor 46/PUUVIII/2010 tentang Uji Materil pasal 2 ayat (2) dan pasal 43 ayat (1) tentang Undang Undang Nomor 1 Tahun 1974, Jurnal, diakses, 25/6/2015

Syafran Sofyan, "Putusan Mahkamah Konstitusi Tentang Status Anak Luar Kawin", http// www.lemhanas.go.id, diunduh pada tanggal 20, juli 2015

Undang-Undang dan Perturan Pemerintah, Fatwa:

Undang-Undang Nomor 1 Tahun 1974 Tentang Perkawinan

Undang-Undang Nomor 35 tentang Perlindungan Anak

PP Nomor 9 Tahun 1975 Sebagai Peraturan Pelaksanaan Undang Undang Nomor 1 Tahun 1974 Tentang Perkawinan.

Putusan Mahkamah Konstitusi Nomor 46/ PUU-VIII/2010 tentang Status Anak Luar Nikah.

Fatwa Majelis Ulama Indonesia nomor 11 Tahun 2012 tentang Kedudukan anak zina dan perlakuan terhadapnya 